\title{
PENERAPAN MODEL PEMBELAJARAN THINK PAIR SHARE UNTUK MENINGKATKAN PEMAHAMAN MAHASISWA TENTANG HAKIKAT WACANA PADA MATAKULIAH WACANA BAHASA INDONESIA
}

\author{
Nahnu Robid Jiwandono \\ Universitas Islam Negeri Walisongo Semarang
}

\begin{abstract}
Abstrak
Penelitian ini bertujuan untuk meningkatkan pemahaman mahasiswa terkait hakikat wacana pada Matakuliah Wacana Bahasa Indonesia. Penelitian ini dilakukan pada mahasiswa semester $\mathrm{V}$ yang sedang menempuh Matakuliah Wacana Bahasa Indonesia. Penelitian ini merupakan Penelitian Tindakan Kelas (PTK) dengan tindakan berupa penerapaan model pembelajaran Think Pair Share. Instrumen penelitian yang digunakan adalah lembar observasi dan tes akhir siklus yang berisi soal sesuai indikator pemahaman konsep. Penelitian ini dilaksanakan dalam dua siklus. Pada siklus pertama, hasil tes menunjukkan bahwa sebagian besar mahasiswa mendapatkan hasil kurang maksimal. Pemahaman mahasiswa terkait wacana dapat dikatakan masih kurang. Selanjutnya dilakukan tindakan penerapan model pembelajaran Think Pair Share dengan fokus pada pemantapan konsep terakit hakikat wacana. Pada siklus kedua ini, didapatkan hasil yang menunjukkan peningkatan yang signifikan terkait hasil belajar mahasiswa. Jadi, indikator keberhasilan sudah tercapai sehingga tidak perlu dilaksanakan siklus selanjutnya. Dengan demikian, dapat disimpulkan bahwa model pembelajaran Think Pair Share terbukti dapat meningkatkan pemahaman mahasiswa terkait hakikat wacana.
\end{abstract}

Kata Kunci: Wacana Bahasa Indonesia, Think Pair Share

\begin{abstract}
This study aims to improve students' understanding of the nature of discourse in the Indonesian Language Discourse Course. This research was conducted on fifth semester students who were taking the Indonesian Language Discourse Course. This research is a Classroom Action Research (CAR) with the action of applying the Think Pair Share learning model. The research instrument used was an observation sheet and an end-of-cycle test containing indicators of concept understanding. This research was conducted in two cycles. In the first cycle, the test results showed that most students got less than optimal results. Students' understanding of discourse can be said to be still lacking. Next, the implementation of the Think Pair Share learning model was carried out with a focus on strengthening the concept of the nature of discourse. In this second cycle, the results obtained showed a significant increase in student learning outcomes. So, the indicators of success have been achieved so there is no need to carry out the next cycle. Thus, it can be said that the Think Pair Share learning model is proven to be able to increase students' understanding of the nature of discourse.
\end{abstract}

Keywords: Indonesian Language Discourse, Think Pair Share

\section{PENDAHULUAN}

Pada era perkembangan teknologi dan informasi yang begitu pesat sekarang ini, isu mengenai perubahan paradigma pendidikan menjadi permasalahan yang hangat dibicarakan. Seiring perkembangan pada berbagai aspek kehidupan manusia, pendidikan yang menjadi salah satu aspek yang berperan penting pada perubahan itu sendiri sudah seharusnya juga mengalami perubahan atau penyesuaian. Berdasarkan penjelasan Krulik dan Rudnick (1996), perubahan tersebut meliputi kurikulum, pembelajaran, dan asesmen yang komprehensif.

Pendidik sebagai perencana dan pelaksana pembelajaran sudah seharusnya dapat dengan kreatif memilih dan memodifikasi model pembelajaran yang relevan dengan karakteristik peserta didik dan materi yang diajarkan. Paradigma pendekatan behavioristik sudah seharusnya mulai bergeser kepada pendekatan konstruktivistik dan kooperatif. Salah satu model pembelajaran yang dapat digunakan dalam pembelajaran di berbagai tingkat 
atau jenjang pendidikan adalah model pembelajaran Think Pair Share. Model pembelajaran ini memberikan pengalaman belajar aktif dan kooperatif bagi peserta didik. Dengan model pembelajaran ini, diharapkan peserta didik dapat aktif berpikir, bekerja sama, dan berbagi pengetahuan yang dimiliki terkait materi yang dipelajari.

Berdasarkan studi pendahuluan pada subjek penelitian dalam penelitian ini, didapatkan hasil bahwa pemahaman mahaiswa terkait berbagai konsep pada materi hakikat wacana masih kurang. Hal ini terlihat dari pada awal perkuliahan dan terlibat tanya-jawab dengan dosen, mereka menunjukkan respons yang cenderung pasif dan menunjukkan kebingungan dalam memahami konsep-konsep pada materi hakikat wacana. Berdasarkan permasalahan yang ditemukan pada mata kuliah Wacana Bahasa Indonesia ini, butuhkan suatu alternatif model pembelajaran yang dapat meningkatkan pemahaman mahasiswa terkait konsep wacana. Salah satu model pembelajaran yang dapat menjadi alternatif penyelesaian permasalahan tersebut adalah model pembelajaran Think Pair Share.

Dalam penelitian ini, digunakan tindakan berupa penerapan model pembelajaran pada subjek penelitian dengan harapan dapat meningkatkan kemampuan atau pemahaman mahasiswa. Gunter dkk. (1990:67) menjelaskan bahwa model pembelajaran seabagai an instructional model is a step-by-step procedure that leads to specific learning outcomes. Sementara itu, Joyce \& Weil (1980) mendefinisikan model pembelajaran sebagai kerangka konseptual yang digunakan sebagai pedoman dalam melakukan pembelajaran. Jadi, model pembelajaran merupakan kerangka konseptual yang di dalamnya terdapat prosedur yang sistematis dalam mengorganisasikan pengalaman belajar untuk mencapai tujuan pembelajaran. Istilah model pembelajaran cenderung relatif sulit dibedakan dengan strategi pembelajaran. Keduanya relatif sama dalam sintax pembelajaran.

Seiring berkembangnya zaman dan teknologi, paradigma pendidikan mengalami pergeseran dan perubahan. Pergeseran tata cara penyelenggaraan kegiatan pendidikan dan pembelajaran terlihat dalam beberapa aspek. Pergeseran itu meliputi proses pembelajaran: dari berpusat pada guru menuju berpusat pada siswa, dari satu arah menuju interaktif, dari isolasi menuju lingkungan jejaring, dari pasif menuju aktif-menyelidiki, dari maya/abstrak menuju konteks dunia nyata, dari pribadi menuju pembelajaran berbasis tim, dan aspek lain yang mengalami dinamika (BSNP, 2010:48). Salah satu hal yang penting dan turut andil dalam keberhasilan proses pembelajaran adalah model pembelajaran. Model pembelajaran yang dapat menjadi alternatif dan diharapkan mampu membuat pembelajaran lebih optimal sehubungan dengan perubahan dalam beberapa aspek seperti sekarang ini salah satunya adalah model pembelajaran think pair share. Model ini menekankan pada keaktifan proses berpikir (think) serta melibatkan aspek kolaboratif (pair-share) dalam pelaksanaannya. Hal ini disebabkan karena dalam model pembbelajaran think pair share terdapat aspek kolaborasi yang menuntut peserta didik berinteraksi satu sama lain sehingga dapat memperkaya pengetahuan dari berbagai sudut pandang. Seperti yang diyatakan oleh Joyce dkk. (1980) interaksi yang terjadi antar peserta didik berkorelasi positif terhadap kemampuan kognitifnya.

Beberapa penelitian yang telah menemukan hasil yang positif terkait penggunaan model pembelajaran ini adalah sebagai berikut. Arnidha (2016:136) menyimpulkan bahwa model pembelajaran think pair share dinilai lebih baik dibandingkan dengan pembelajaran konvensional pada aspek kemampuan peserta didik. Sejalan dengan hasil penelitian tersebut, Ambarwati (2012) dalam penelitiannya menemukan bahwa pembelajaran dengan menggunakan model pembelajaran think pair share dapat membuat siswa berpikir kritis dan menguatkan tingkat penguasaan konsep. Selain itu, Surayya (2014:09) melalui penelitiannya juga menemukan bahwa pembelajaran dengan model pembelajaran think pair share, secara umum dapat 
meningkatkan hasil pembelajaran peserta didik. Penelitian-penelitian tersebut juga diperkuat oleh hasil penelitian Sukasari (2012) yang menyatakan bahwa penerapan model pembelajaran think pair share berdampak positif dalam meningkatkan hasil belajar peserta didik. Penelitianpenelitian yang telah disebutkan di atas diterapkan pada tingkatan sekolah menengah pada bidang ilmu eksak yang ternyata membuktikan kefektifan model pembelajaran think pair share untuk meningkatkan hasil belajar. Oleh karena itu, dalam penelitian ini, peneliti berusaha untuk mendeskripsikan kefektifan model pembelajaran ini pada tingkat mahasiswa (semester V) pada bidang ilmu bahasa, khususnya pada matakuliah wacana bahasa Indonesia.

\section{METODE PENELITIAN}

Penelitian ini merupakan Penelitian tindakan kelas (PTK) yang bertujuan untuk memberikan tindakan atau perlakuan khusus untuk meningkatkan aspek-aspek yang menjadi sasaran pada sebuah subjek atau objek penelitian. Pada penelitian ini, tindakan yang digunakan adalah penerapan sebuah model atau strategi pembelajaran Think Pair Share.

Penelitian Tindakan Kelas (PTK) adalah terjemahan dari Classroom Action Research. Carr \& Kemmis (dalam McNiff, 1991) mendefinisikan PTK dalam beberapa poin penting sebagai berikut. Pertama, penelitian tindakan adalah satu bentuk inkuiri atau penyelidikan yang dilakukan melalui refleksi diri. Kedua, penelitian tindakan dilakukan oleh peserta yang terlibat dalam situasi yang diteliti, seperti guru, siswa, atau kepala sekolah. Ketiga, penelitian tindakan dilakukan dalam situasi sosial, termasuk situasi pendidikan. Keempat, tujuan penelitian tindakan adalah memperbaiki: dasar pemikiran dan kepantasan dari praktik-praktik, pemahaman terhadap praktik tersebut, serta situasi atau lembaga tempat praktik tersebut dilaksanakan.

Subjek penelitian ini adalah mahasiswa semester V Program Studi Pendidikan Bahasa Indonesia Universitas
Islam Malang. Objek yang mejadi fokus penelitian adalah pemahaman mahasiswa terkait hakikat wacana pada Matakuliah Wacana Bahasa Indonesia. Peneliti menggunakan instrumen berupa tes pilihan ganda atau multiple choice terkait mater hakikat wacana pada dua siklus yang berbeda. Siklus kedua diharapkan mendapatkan hasil yang lebih optimal dibandingkan siklus pertama. Perbedaan kedua siklus ini terletak dari tindakan berupa penerapan strategi pembelajaran Think Pair Share dan adanya evaluasi atau refleksi terhadap pembelajaran pada siklus yang pertama.

Pendekatam yang digunakan dalam penelitian ini adalah pendekatan kualitatif dengan jenis Penelitian Tindakan Kelas (PTK). PTK dilaksanakan dalam siklus yang terus berulang sampai indikator keberhasilan tindakan tercapai. Tiap siklus terdiri 4 tahapan yaitu plan (perencanaan), act (tindakan), observe (observasi), reflect (refleksi).

Tahap perencanaan (plan). Pada tahap ini, peneliti merencanakan tindakan yang akan diberikan dalam rangka mengembangkan pemahaman mahasiswa terkait hakikat wacana. Selain itu, peneliti menyusun instrumen berupa soal atau tes berbentuk pilihan ganda (PG) yang digunakan untuk menguji pemahaman mahasiswa.

Tahap tindakan (act) dan observasi (observe). Pada saat pelaksanaan tindakan, tim peneliti berperan sebagai pengajar dan pendamping lapangan. Anggota tim peneliti yang tidak bertugas sebagai pendamping lapangan berperan dalam membantu mengkondisikan peserta didik sekaligus bertugas sebagai observer pelaksanaan tindakan. Pada tahap ini, observer mengobservasi jalannya tindakan sesuai lembar observasi dan mencatat hal yang penting dalam catatan lapangan.

Tahap refleksi (reflect). Pada tahap ini, dilakukan diskusi hasil observasi saat pelaksanaan tindakan dan hasil tes akhir siklus. Setelah memeriksa hasil tindakan yang dilakukan dan tes akhir siklus, kemudian disesuaikan dengan indikator keberhasilan tindakan untuk mengetahui 
perlu atau tidaknya dilakukan siklus selanjutnya.

\section{HASIL DAN PEMBAHASAN}

Hasil tes pada siklus satu menunjukkan bahwa sebagian besar mahasiswa memperoleh nilai yang masih cenderung rendah. Mahasiswa yang mendapatkan nilai lebih dari atau sama dengan 80 hanya berjumlah lima (5) orang atau $18 \%$ dari total 28 mahasiswa yang mengikuti tes pada siklus pertama. Sementara itu, 8 orang mahasiswa atau $29 \%$ mendapatkan nilai di antara rentangan 70-79 dan terdapat 15 mahasiswa atau $53 \%$ yang mendapatkan nilai kurang dari 70. Jadi, dapat disimpulkan bahwa lebih dari separuh mahasiswa memperoleh nilai di bawah 80 . Hal ini berarti mereka mendapatkan nilai yang masih di bawah kriteria untuk mendapatkan nilai A pada mata kuliah Wacana Bahasa Indonesia. Hasil siklus 1 lebih lanjut dapat dilihat pada diagram berikut ini.

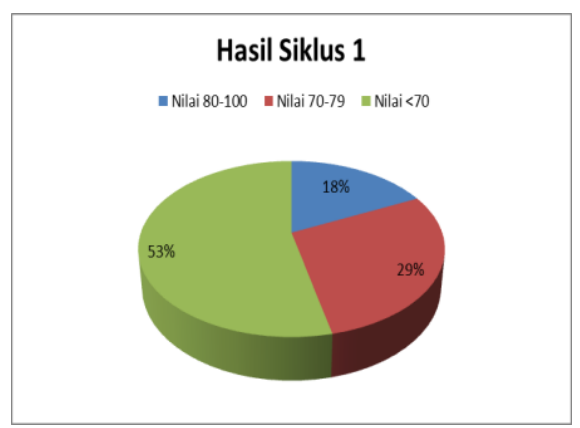

Gambar 1. Hasil Tes Pada Siklus 1

Sementara itu, pada siklus kedua menunjukkan peningkatan nilai hasil tes yang diperoleh mahasiswa. Pada siklus kedua, secara umum terjadi peningkatan nilai yang signifikan pada sebagian besar mahasiswa. Mahasiswa yang mendapatkan nilai lebih dari atau sama dengan 17 orang atau $61 \%$ dari total 28 mahasiswa yang mengikuti tes pada siklus kedua. Sementara itu, 7 orang mahasiswa atau $25 \%$ mendapatkan nilai di antara rentangan 7079 dan terdapat 4 mahasiswa atau $14 \%$ yang mendapatkan nilai kurang dari 70 . Dengan hasil ini, dapat disimpulkan bahwa terdapat peningkatan nilai siswa yang siginifikan dilihat dari jumlah mahasiswa yang mendapatkan nilai A atau di atas 80 sudah mencapai lebih dari 50\%. Lenih lanjut, hasil tes pada siklus 2 dapat dilihat pada diagram 2 berikut ini.

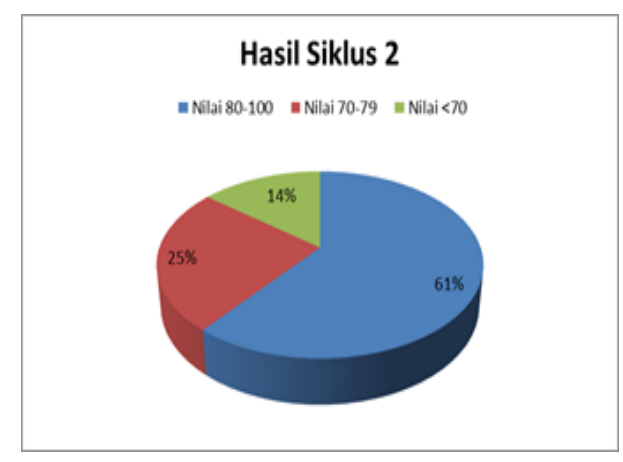

Gambar 2. Hasil Tes Pada Siklus 2

Jadi, secara umum dapat dikatakan bahwa penerapan model strategi pembelajaran Think Pair Share dapat meningkatkan pemahaman siswa terkait konsep hakikat wacana pada mata kuliah Wacana Bahasa Indonesia. Penerapan model atau strategi pembelajaran Think Pair Share dapat menguatkan pemahaman konsep mahasiswa karena memberikan pengalaman belajar bagi mahasiswa untuk bekerja sama dan bertukar pikiran atau gagasan tentang berbagai konsep pada materi hakikat wacana. Hal ini juga sesuai dengan pendapat mahasiswa yang mengisi kuesioner terkait pengalaman belajar yang diadapatkan dengan penerapan model atau strategi pembelajaran Think Pair Share ini. Menurut sebagian besar mahasiswa, penerapan model pembelajaran ini memberikan lebih banyak kesempatan pada mahasiswa untuk bertukar pendapat, berdiskusi, dan akhirnya dapat menguatkan pemahan mereka terkait hakikat wacana secara umum.

\section{SIMPULAN}

Berdasarkan pembahasan hasil penelitian yang telah dipaparkan di atas, dapat disimpulkan bahwa pemberian tindakan berupa penerapan strategi pembelajaran Think Pair Share berkorelasi positif terhadap pemahaman mahasiswa terkait hakikat wacana. Hal ini dapat dilihat dari hasil tes pada siklus pertama dan siklus kedua. Pada siklus kedua, nilai atau hasil 
tes mahasiswa menunjukkan peningkatan yang signifikan dibandingkan siklus yang pertama.

Penulis berharap semakin banyak kajian-kajian atau penelitian serupa yang dilakukan guna untuk meningkatkan kualitas pembelajaran di kelas. Tidak hanya di tingkat perguruan tinggi, model

\section{DAFTAR RUJUKAN}

Ambarwati, A.D. 2012. "Model Pembelajaran Kooperatif Tipe ThinkPair-Share (TPS) dengan Pendekatan Inquiry untuk Meningkatkan Keterampilan Berfikir Kritis dan Penguasaan Konsep Siswa SMP pada Konsep Tekanan”. www.repository.upi.edu. Diunduh tanggal 01 Oktober 2021.

Arnidha, Y. 2016. Peningkatan Kemampuan Representasi Representasi Matematis melalui Model Pembelajaran Kooperatif Think Pair Share. Jurnal E-DuMath. 2(1): 128137.

BSNP. 2010. Paradigma Pendidikan Nasional Abad XXI. Jakarta: Badan Standar Pendidikan Nasional.

Gunter, M. A., Estes, T. H., \& Schwab, J. H. 1990. Instruction: A models approach. Boston: Allyn and Bacon.

Idris, N. 2009. Enhancing Students' Understanding In Calculus Trough pembelajaran atau strategi pembelajaran Think Pair Share juga diharapkan dapat diterapkan pada jenjang pendidikan yang lain. Peneliti lain juga dapat menguji kefektifan model atau strategi pembelajaran Think Pair Share ini pada materi atau mata kuliah yang lain, yang tentunya memiliki karakteristik yang berbeda-beda.

Writing. International Electronic Journal of Mathematics Education, 4 (1): 36-55.

Joyce, B., \& Weil, M. 1980. Model of teaching. New Jersey: Prentice-Hall, Inc

McNiff, J. 1991. Action Research: Principles and Practice. London: Macmillan.

Sukasari, P. 2012. Pengaruh Model Pembelajaran Kooperatif Tipe Think Pair Share Terhadap Hasil Belajar Siswa Kelas XI IPA SMA Negeri 4 Singaraja. Skripsi. (tidak diterbitkan). Singaraja: Jurusan Pendidikan Kimia Undiksha.

Surayya, L., Subagia, W., \& Tika, N. 2014. Pengaruh Model Pembelajaran Think Pair Share terhadap Hasil Belajar IPA Ditinjau dari Keterampilan Berpikir Kritis Siswa. E-Journal Program Pascasarjana Universitas Pendidikan Ganesha Program Studi IPA. 4(1): 111. 